\title{
Nutritional Indices and Cardiovascular Risk Factors in HIV Infection in Southern Nigeria
}

\author{
Augusta Chinyere Nsonwu-Anyanwu ${ }^{1 *}$, Edmund Richard Egbe ${ }^{1}$, \\ Chidozie Elochukwu Agu ${ }^{1}$, Sunday Jeremiah Offor ${ }^{1}$, Chinyere Adanna Opara Usoro ${ }^{1}$, \\ Isaac Asuquo Essien', Clementina Arit Okon'1. \\ ${ }^{1}$ Chemical Pathology Unit, Dept. of Medical Laboratory Science, University of Calabar, Cross River State, Nigeria.
}

\begin{abstract}
Background: Viral load and specific drug related toxicities have been implicated in nutritional and metabolic disturbances in HIV infection. This study evaluated some micro, macro nutrients and cardiovascular risk factors in HIV infection with or without highly active antiretroviral therapy (HAART).

Material and Methods: Ninety subjects (18-65 years) comprising of 30 sero-positive HIV on HAART, 30 sero-positive HAART naïve and 30 HIV sero-negative subjects were recruited into the study. Fasting plasma glucose (FPG), total proteins (TP), albumin, vitamin C, total cholesterol (TC), triglycerides (TG), high density lipoprotein cholesterol (HDLC) were estimated using colorimetric methods, zinc $(\mathrm{Zn})$, copper $(\mathrm{Cu})$ by atomic absorption spectrophotometry, CD4+ $\mathrm{T}$ cell count by flow cytometry while body mass index (BMI), globulin, atherogenic index of plasma (AIP), albumin/globulin ratio $(\mathrm{A} / \mathrm{G})$, very low density lipoprotein cholesterol (VLDL-C), low density lipoprotein cholesterol (LDL-C) were calculated. Data were analyzed using ANOVA, LSD post hoc at $\mathrm{p}<0.05$.

Results: HIV sero-negative subjects had higher BMI, CD4-T cell count, albumin, vitamin C, Zn, LDL-C, A/G ratio and lower FPG, globulin, $\mathrm{Cu}$ compared to HAART naïve; and higher BMI, CD4+T cell count, albumin, vitamin $\mathrm{C}$, $\mathrm{Zn}$ with lower FPG, globulin, $\mathrm{Cu}, \mathrm{TG}$, and VLDLC compared to HIV on HAART respectively $(\mathrm{p}<0.05)$. HIV on HAART had increased albumin, A/G ratio, FPG, LDLC, VLDL, TG, TC and lower CD4 + T cell count, TP, globulin and Zn compared to HAART naive subjects $(\mathrm{p}<0.05)$.

Conclusion: Disturbances in homeostasis of total proteins, antioxidant micronutrients with dyslipidemia and increased risk of cardiovascular disorders in HIV infection may be aggravated by HAART.
\end{abstract}

Key words: $H A A R T, H I V$, lipid profile, micronutrients, proteins

\section{Introduction}

HIV viremia and highly active antiretroviral therapy (HAART) have been implicated in the development of metabolic disturbances associated with increased risks for development of cardiovascular diseases in HIV infection (1). Lipid abnormalities characterized by a decrease in the plasma concentrations of TC, HDL-C and LDL-C and an elevation of TG in later stage of infection are rife in HIV infection (2). Dyslipidemia characterized by hypertriglyceridemia, hypercholesterolemia, and decreased serum levels of HDL-C, either accompanied or

*Corresponding Author: Augusta Chinyere NsonwuAnyanwu, Chemical Pathology Unit, Department of Medical Laboratory Science, University of Calabar, PMB 1115 Calabar, Cross River State, Nigeria. E-mail: austadechic@yahoo.com Phone: +2348033515095 Received: Dec 30, 2016. Accepted: Mar 16, 2017 not by increased levels of LDL-C have been associated with HAART (1). Insulin resistance, impaired glucose tolerance, impaired fasting glucose and diabetes mellitus are glucose metabolism disorders also reported in persons with HIV infection with and without HAART (2). The exact etiologic mechanisms for development of these disorders are still uncertain because not all of the patients exposed to the same HAART regimens are similarly affected. Alterations in acute phase response proteins in response to acute or chronic inflammation and

This is an Open Access article distributed under the terms of the Creative Commons Attribution Non-Commercial License (http://creativecommons.org/licenses/bync/4.0/) which permits unrestricted non-commercial use, distribution, and reproduction in any medium, provided the original work is properly cited.

Journal of Immunology and Clinical Microbiology (C 2017 
abnormalities in B-cell function in terms of hypergammaglobulinemia and hypogammaglobulinaemia are also some of the consequences of HIV infection. These results in either raised or decreased level of total plasma protein depending on which component of immune deregulation predominates (3). Changes in acute phase response proteins, mainly decreased albumin and elevated C-reactive protein concentrations, have been shown to be associated with low serum concentrations of several micronutrients in HIV-positive subjects not receiving HAART (4). Depression of cell mediated immune response, decreased lymphocyte concentrations, reduced cytokine response, and defective neutrophils and $\mathrm{T}$ cell functions have been associated with deficiencies of vitamin $\mathrm{C}, \mathrm{Zn}, \mathrm{Cu}$, and $\mathrm{Se}$ respectively. Micronutrient deficiencies have been associated with increased risk of HIV disease progression and mortality and supplementation with delay in HIV disease progression and reduced mortality $(4,5)$.

Studies that focused on disturbances in lipid metabolism associated with HIV and HAART in Nigeria are few compared to the menace of HIV infection, fewer investigations still, have attempted to characterize the cardiovascular risk factors in combination with disturbances in the homeostasis of some micro and macro nutrients in HIV sero-positive individuals and changes following HAART initiation. This information will be important for monitoring the dosing of HAART, improved quality of life and increase life expectancy of people living with HIV. This study therefore evaluated some micro, macro nutrients and cardiovascular risk factors in HIV infection with or without highly active antiretroviral therapy (HAART) in South-South Nigeria.

\section{Material and methods}

\section{Selection of subjects}

Participants were recruited at the Voluntary Counseling and Testing (VCT) unit and HIV Clinic of University of Calabar Teaching Hospital, (UCTH) Calabar, SouthSouth Nigeria from September to November, 2015. The study protocol was approved by Cross Rivers State, Nigeria Ministry of Health. Ninety subjects were recruited for the study which comprised; 30 HIV seropositive subjects on HAART, 30 HAART naïve HIV sero-positive subjects and 30 apparently healthy aged matched sero-negative individuals who served as controls. The HIV sero-positive patients on HAART have been on any of the HAART regimens corresponding with the WHO consolidated guidelines on the use of antiretroviral drugs for treating and preventing HIV infection (6) for a minimum of six months. Informed written consent was obtained from all subjects before recruitment into the study. Subjects with full blown AIDS, other comorbidities as tuberculosis, hepatitis B or $\mathrm{C}$ viral infection, pregnant women, lactating mothers and those who did not give consent were excluded from the study. This study was carried out in accordance with the Ethical Principles for Medical Research Involving Human Subjects as outlined in the Helsinki Declaration in 1975 and subsequent revisions.

\section{Sample Collection}

Six milliliters of whole blood samples $(6 \mathrm{ml})$ were collected by venipuncture with minimum stasis and aliquoted as follows; $3 \mathrm{ml}$ was dispensed into vacutainer tubes containing di-potassium ethylenediaminetetraacetic acid ( $\mathrm{K}_{2}$ EDTA) salt for CD4+T cell count and $3 \mathrm{ml}$ into plain specimen container, the sample was allowed to clot and retract and centrifuged for 10 minutes at 3500 revolutions per minutes. Sera was separated and kept immediately frozen at $-20^{\circ} \mathrm{C}$ until the time of analysis.

\section{Laboratory Methods}

Hepatitis B surface antigen and antibody to hepatitis C virus were determined using ELISA. HIV screening and confirmation were carried out using Determine, Stat pak and Uni-Gold rapid test kits; the test was based on immunochromatographic principle (7).

Enumeration of CD4+ T cell count was done by flow cytometry using the automated partec cyflow counter (8).

Total cholesterol and triglyceride were determined using enzymatic colorimetric method (9) (10), while high density lipoprotein cholesterol was determined using the precipitation cholesterol enzymatic method (11). The test kits were obtained from EliTech clinical systems (SASZone Industrielle- 61500 SEES France).

Very low density lipoprotein-cholesterol concentration was calculated from the triglyceride concentration using 
the Friedewal et al., (12) formula; VLDL = Triglyceride concentration/ 2.2.

Low density lipoprotein cholesterol concentration was calculated from the total cholesterol concentration, HDLcholesterol concentration and the triglyceride concentration using the Friedewal et al., formula (12); $\mathrm{LDL}-\mathrm{C}(\mathrm{mmol} / \mathrm{L})=$ Total cholesterol - HDL $-\mathrm{C}-$ (Triglyceride)/2. 2.

Atherogenic index of plasma (AIP) was calculated from the concentrations of triglyceride and high density lipoprotein cholesterol (HDL) using the formula (13);

$\mathrm{AIP}=\log (\mathrm{TG}(\mathrm{mmol} / \mathrm{L})) / \mathrm{HDL}(\mathrm{mmol} / \mathrm{L})$

Vitamin $\mathrm{C}$ was estimated using the modified reduction method (14).

Total proteins were determined using the Biuret method (15). The test kit was obtained from Randox Laboratories Limited United Kingdom.

Serum albumin was determined using the Bromocresol Green (BCG) method (16). The test kits were also obtained from Randox Laboratories Limited United Kingdom.

Globulin was calculated from the concentration of total protein and albumin using the formula;

Globulin $=$ total protein $(\mathrm{g} / \mathrm{dL})-$ albumin $(\mathrm{g} / \mathrm{dL})$,

Albumin/globulin ratio was obtained by dividing the albumin concentration with that of globulin.

Zinc and copper were estimated using atomic absorption spectrophotometry (17).

\section{Statistical Analysis}

Data analysis was done using the statistical package for social sciences (SPSS version 20.0, California Inc.). Analysis of variance (ANOVA) was used to test significance of variations within and among group means and Fisher's least significant difference (LSD) post hoc test was used for comparison of multiple group means. A probability value $p<0.05$ was considered statistically significant.

\section{Results}

The comparison of age, CD4+ $\mathrm{T}$ cell counts, macronutrients (total protein, albumin, globulin, albumin/globulin ratio) and micronutrients (vitamin $\mathrm{C}$, zinc and copper) in HIV sero-subjects on HAART, HAART naïve and sero-negative controls were shown in table 1. Significant variations were observed in the CD4+ cell count, total protein, albumin, globulin, albumin/globulin ratio, vitamin $\mathrm{C}$, zinc and copper among the three groups studied $(\mathrm{p}<0.05)$, while no significant variation was observed in their ages $(p>0.05)$. The comparison of $\mathrm{CD} 4+\mathrm{T}$ cell count, macro and micronutrients among the 3 groups studied using LSD post hoc were depicted in table 2. HIV sero-negative controls had significantly higher CD4+ $\mathrm{T}$ cell count, albumin, vitamin $\mathrm{C}$ and zinc and lower levels of globulin and copper compared to HIV sero-positive subjects on HAART $(\mathrm{p}<0.05)$ and significantly higher CD4+ T cell count, albumin, $\mathrm{A} / \mathrm{G}$ ratio, vitamin $\mathrm{C}$ and zinc and lower globulin and copper compared to the HAART naïve subjects $(\mathrm{p}<$ 0.05). HIV sero-positive subjects on HAART had significantly higher levels of albumin and $\mathrm{A} / \mathrm{G}$ ratio and lower levels of CD4+ T cells count, total protein, globulin and zinc compared to HAART naïve sero-positive subjects $(\mathrm{p}<0.05)$.

Comparison of markers of cardiovascular risk factors (BMI, FPG, TC, TG, LDL-C, HDL-C, VLDL-C, and AIP) in HIV subjects on HAART, HAART naïve and sero-negative controls were shown in table 3 . The BMI, TC, TG, LDL-C, VLDL-C and AIP varied significantly among the three groups $(\mathrm{p}<0.05)$, while no significant variation was observed in the HDL-C levels among the groups ( $p>0.05)$.

Comparison of markers of cardiovascular risk factors among the three groups studied using LCD post hoc were shown in table 4. HIV sero-negative controls had significantly higher BMI and lower FPG, TG, VLDL-C and AIP compared to HIV sero-positive subjects on HAART ( $\mathrm{p}<0.05$ ), and significantly higher BMI, LDL-C and lower FPG compared to the HAART naïve subjects $(\mathrm{p}<0.05)$. HIV sero-positive subjects on HAART had significantly higher levels of FPG, TC, TG, LDL-C, VLDL and AIP compared to HAART naïve subjects studied $(\mathrm{p}<0.05)$. 
Table 1. Comparison of age, $C D 4^{+} T$ cell count, micro and macro nutrients in HIV seropositive subjects on HAART, HAART naive and sero-negative controls.

\begin{tabular}{llllll}
\hline Parameter & $\begin{array}{l}\text { HAART } \\
\mathbf{n}=\mathbf{3 0}\end{array}$ & $\begin{array}{l}\text { HAART NAIVE } \\
\mathbf{n}=\mathbf{3 0}\end{array}$ & $\begin{array}{l}\text { Controls } \\
\mathbf{n = 3 0}\end{array}$ & F- ratio & p value \\
\hline Age $(\mathrm{years})$ & $35.80 \pm 8.64$ & $32.53 \pm 8.74$ & $34.13 \pm 8.94$ & 1.04 & 0.358 \\
$\mathrm{CD} 4^{+} \mathrm{T}(\mathrm{cells} / \mathrm{ml})$ & $486.63 \pm 300.5$ & $683.13 \pm 250.7$ & $1083.70 \pm 442.3$ & 23.89 & $0.000^{*}$ \\
$\mathrm{TP}(\mathrm{g} / \mathrm{dl})$ & $68.23 \pm 6.44$ & $77.60 \pm 13.93$ & $73.70 \pm 10.25$ & 5.85 & $0.004^{*}$ \\
$\mathrm{ALB}(\mathrm{g} / \mathrm{dl})$ & $32.73 \pm 5.53$ & $23.53 \pm 6.79$ & $45.30 \pm 8.91$ & 74.81 & $0.000^{*}$ \\
$\mathrm{GLO}(\mathrm{g} / \mathrm{dl})$ & $35.83 \pm 6.69$ & $54.07 \pm 13.72$ & $28.77 \pm 8.91$ & 49.12 & $0.000^{*}$ \\
$\mathrm{~A} / \mathrm{G}$ ratio & $1.95 \pm 0.31$ & $0.47 \pm 0.22$ & $1.76 \pm 0.74$ & 84.87 & $0.000^{*}$ \\
$\mathrm{Vit} \mathrm{C}(\mathrm{mg} / \mathrm{dl})$ & $0.28 \pm 0.10$ & $0.31 \pm 0.09$ & $0.42 \pm 0.13$ & 15.01 & $0.000^{*}$ \\
$\mathrm{Zn}(\mu \mathrm{g} / \mathrm{dl})$ & $45.31 \pm 30.41$ & $84.30 \pm 36.52$ & $111.47 \pm 19.57$ & 37.67 & $0.000^{*}$ \\
$\mathrm{Cu}(\mu \mathrm{g} / \mathrm{dl})$ & $112.72 \pm 24.66$ & $121.54 \pm 17.89$ & $100.56 \pm 15.14$ & 8.62 & $0.000^{*}$ \\
\hline
\end{tabular}

* Significant at $\mathrm{p}<0.05, \mathrm{TP}=$ total protein, $\mathrm{ALB}=$ albumin, $\mathrm{GLO}=$ globulin, $\mathrm{A} / \mathrm{G}$ ratio = albumin/globulin ratio.

Table 2. Comparison of $C D 4^{+} \mathrm{T}$ cell count, micro and macronutrients in HIV sero-positive subjects on HAART, HAART naive and sero-negative controls using LCD post hoc.

\begin{tabular}{|c|c|c|c|c|}
\hline Parameter & Groups & & Mean diff. & p value \\
\hline & HAART $n=30$ & Controls $\mathrm{n}=30$ & & \\
\hline $\mathrm{CD}^{+} \mathrm{T}($ cells/ml) & $486.63 \pm 300.5$ & $1083.70 \pm 442.3$ & $-597.1 \pm 88.0$ & $0.000 *$ \\
\hline $\operatorname{ALB}(\mathrm{g} / \mathrm{dl})$ & $32.73 \pm 5.53$ & $45.30 \pm 8.91$ & $-12.57 \pm 1.79$ & $0.000 *$ \\
\hline GLO (g/dl) & $35.83 \pm 6.69$ & $28.77 \pm 8.91$ & $7.07 \pm 2.63$ & $0.009 *$ \\
\hline Vit C (mg/dl) & $0.28 \pm 0.10$ & $0.42 \pm 0.13$ & $-0.15 \pm 0.03$ & $0.000 *$ \\
\hline $\mathrm{Zn}(\mu \mathrm{g} / \mathrm{dl})$ & $45.31 \pm 30.41$ & $111.47 \pm 19.57$ & $-66.16 \pm 7.66$ & $0.000 *$ \\
\hline \multirow[t]{2}{*}{$\mathrm{Cu}(\mu \mathrm{g} / \mathrm{dl})$} & $112.72 \pm 24.66$ & $100.56 \pm 15.14$ & $12.16 \pm 5.07$ & $0.019 *$ \\
\hline & HAART NAÏVE $n=30$ & Controls $n=30$ & & \\
\hline $\mathrm{CD}^{+} \mathrm{T}($ cells $/ \mathrm{ml})$ & $683.13 \pm 250.7$ & $1083.70 \pm 442.3$ & $-400.6 \pm 88.0$ & $0.000 *$ \\
\hline $\operatorname{ALB}(\mathrm{g} / \mathrm{dl})$ & $23.53 \pm 6.79$ & $45.30 \pm 8.91$ & $-21.77 \pm 1.79$ & $0.000^{*}$ \\
\hline GLO (g/dl) & $54.07 \pm 13.72$ & $28.77 \pm 8.91$ & $25.30 \pm 2.63$ & $0.000 *$ \\
\hline $\mathrm{A} / \mathrm{G}$ ratio & $0.47 \pm 0.22$ & $1.76 \pm 0.74$ & $-1.28 \pm 0.12$ & $0.000 *$ \\
\hline Vit C (mg/dl) & $0.31 \pm 0.09$ & $0.42 \pm 0.13$ & $-0.11 \pm 0.03$ & $0.000 *$ \\
\hline $\mathrm{Zn}(\mu \mathrm{g} / \mathrm{dl})$ & $84.30 \pm 36.52$ & $111.47 \pm 19.57$ & $-27.18 \pm 7.66$ & $0.001 *$ \\
\hline \multirow[t]{2}{*}{$\mathrm{Cu}(\mu \mathrm{g} / \mathrm{dl})$} & $121.54 \pm 17.89$ & $100.56 \pm 15.14$ & $20.97 \pm 5.07$ & $0.000^{*}$ \\
\hline & HAART $n=30$ & HAART NAIVE $n=30$ & & \\
\hline $\mathrm{CD}^{+} \mathrm{T}($ cells/ml $)$ & $486.63 \pm 300.5$ & $683.13 \pm 250.7$ & $-196.5 \pm 88.0$ & $0.028 *$ \\
\hline $\mathrm{TP}(\mathrm{g} / \mathrm{dl})$ & $68.23 \pm 6.44$ & $77.60 \pm 13.93$ & $-9.37 \pm 2.75$ & $0.001 *$ \\
\hline $\operatorname{ALB}(\mathrm{g} / \mathrm{dl})$ & $32.73 \pm 5.53$ & $23.53 \pm 6.79$ & $9.20 \pm 1.79$ & $0.000 *$ \\
\hline $\mathrm{GLO}(\mathrm{g} / \mathrm{dl})$ & $35.83 \pm 6.69$ & $54.07 \pm 13.72$ & $-18.23 \pm 2.63$ & $0.000 *$ \\
\hline $\mathrm{A} / \mathrm{G}$ ratio & $1.95 \pm 0.31$ & $0.47 \pm 0.22$ & $1.48 \pm 0.12$ & $0.000^{*}$ \\
\hline $\mathrm{Zn}(\mu \mathrm{g} / \mathrm{dl})$ & $45.31 \pm 30.41$ & $84.30 \pm 36.52$ & $-38.98 \pm 7.66$ & $0.000 *$ \\
\hline
\end{tabular}

* Significant at $\mathrm{p}<0.05, \mathrm{TP}=$ total protein, $\mathrm{ALB}=$ albumin, $\mathrm{GLO}=$ globulin, $\mathrm{A} / \mathrm{G}$ ratio = albumin/globulin ratio. 
Table 3. Comparison of cardiovascular risk markers in HIV sero-positive subjects on HAART, HAART naive and seronegative control.

\begin{tabular}{llllll}
\hline \multicolumn{1}{c}{ Parameter } & $\begin{array}{l}\text { HAART } \\
\mathbf{n = 3 0}\end{array}$ & $\begin{array}{l}\text { HAART NAIVE } \\
\mathbf{n}=\mathbf{3 0}\end{array}$ & $\begin{array}{l}\text { Controls } \\
\mathbf{n}=\mathbf{3 0}\end{array}$ & F- value & p value \\
\hline BMI $\left(\mathrm{kg} / \mathrm{m}^{2}\right)$ & $22.39 \pm 1.91$ & $21.62 \pm 2.24$ & $23.89 \pm 2.59$ & 7.73 & $0.001^{*}$ \\
FPG $(\mathrm{mmol} / \mathrm{l})$ & $6.06 \pm 1.96$ & $5.25 \pm 1.54$ & $4.21 \pm 0.39$ & 12.19 & $0.000^{*}$ \\
$\mathrm{TC}(\mathrm{mmol} / \mathrm{l})$ & $5.02 \pm 1.88$ & $3.69 \pm 1.08$ & $4.32 \pm 0.91$ & 7.20 & $0.001^{*}$ \\
$\mathrm{TG}(\mathrm{mmol} / \mathrm{l})$ & $1.54 \pm 0.63$ & $1.10 \pm 0.35$ & $1.07 \pm 0.43$ & 8.92 & $0.000^{*}$ \\
VLDL-C(mmol/l) & $0.67 \pm 0.25$ & $0.50 \pm 0.16$ & $0.49 \pm 0.20$ & 6.94 & $0.002^{*}$ \\
$\mathrm{HDL}-\mathrm{C}(\mathrm{mmol} / \mathrm{l})$ & $1.48 \pm 0.67$ & $1.24 \pm 0.36$ & $1.33 \pm 0.30$ & 2.02 & 0.139 \\
$\mathrm{LDL}-\mathrm{C}(\mathrm{mmol} / \mathrm{l})$ & $2.89 \pm 1.41$ & $1.95 \pm 0.89$ & $2.54 \pm 0.87$ & 5.78 & $0.004^{*}$ \\
AIP & $0.14 \pm 0.18$ & $-0.00 \pm 0.14$ & $-0.01 \pm 0.13$ & 8.94 & $0.002^{*}$ \\
\hline
\end{tabular}

* significant at $\mathrm{p}<0.05, \mathrm{TC}=$ Total cholesterol, AIP $=$ atherogenic index of plasma, TG=triglycerides, VLDL-C= very low density lipoprotein cholesterol, HDL-C=high density lipoprotein cholesterol, LDL-C= low density lipoprotein cholesterol, FPG=fasting plasma glucose.

Table 4. Comparison of cardiovascular risk markers in HIV sero-positive subjects on HAART, HAART naïve and seronegative-controls using LCD Post hoc.

\begin{tabular}{|c|c|c|c|c|}
\hline Parameter & Groups & & Mean diff. & $p$ value \\
\hline & HAART $n=30$ & Controls $n=30$ & & \\
\hline BMI $\left(\mathrm{kg} / \mathrm{m}^{2}\right)$ & $22.39 \pm 1.91$ & $23.89 \pm 2.59$ & $-1.49 \pm 0.58$ & $0.012^{*}$ \\
\hline $\mathrm{FPG}(\mathrm{mmol} / \mathrm{l})$ & $6.06 \pm 1.96$ & $4.21 \pm 0.39$ & $1.85 \pm 0.38$ & $0.000^{*}$ \\
\hline $\mathrm{TG}(\mathrm{mmol} / \mathrm{l})$ & $1.54 \pm 0.63$ & $1.07 \pm 0.43$ & $0.47 \pm 0.12$ & $0.000^{*}$ \\
\hline VLDL(mmol/l) & $0.67 \pm 0.25$ & $0.49 \pm 0.20$ & $0.18 \pm 0.05$ & $0.001^{*}$ \\
\hline \multirow[t]{2}{*}{ AIP } & $0.14 \pm 0.18$ & $-0.01 \pm 0.13$ & $0.15 \pm 0.03$ & $0.001^{*}$ \\
\hline & HAART NAÏVE $n=30$ & Controls $n=30$ & & \\
\hline $\mathrm{BMI}\left(\mathrm{kg} / \mathrm{m}^{2}\right)$ & $21.63 \pm 2.23$ & $23.89 \pm 2.59$ & $-2.26 \pm 0.58$ & $0.000^{*}$ \\
\hline $\mathrm{FPG}(\mathrm{mmol} / \mathrm{l})$ & $5.25 \pm 1.54$ & $4.21 \pm 0.39$ & $1.04 \pm 0.38$ & $0.007^{*}$ \\
\hline \multirow[t]{2}{*}{$\mathrm{LDL}(\mathrm{mmol} / \mathrm{l})$} & $1.95 \pm 0.89$ & $2.54 \pm 0.87$ & $-0.59 \pm 0.28$ & $0.039 *$ \\
\hline & HAART $n=30$ & HAART NAÏVE n=30 & & \\
\hline $\mathrm{FPG}(\mathrm{mmol} / \mathrm{l})$ & $6.60 \pm 1.96$ & $5.25 \pm 1.54$ & $0.81 \pm 0.38$ & $0.033^{*}$ \\
\hline $\mathrm{TC}(\mathrm{mmol} / \mathrm{l})$ & $5.02 \pm 1.88$ & $3.69 \pm 1.08$ & $1.33 \pm 0.35$ & $0.000^{*}$ \\
\hline $\mathrm{TG}(\mathrm{mmol} / \mathrm{l})$ & $1.54 \pm 0.63$ & $1.10 \pm 0.35$ & $0.44 \pm 0.12$ & $0.001^{*}$ \\
\hline VLDL(mmol/l) & $0.67 \pm 0.25$ & $0.50 \pm 0.16$ & $0.17 \pm 0.05$ & $0.002^{*}$ \\
\hline $\mathrm{LDL}(\mathrm{mmol} / \mathrm{l})$ & $2.89 \pm 1.41$ & $1.95 \pm 0.89$ & $0.94 \pm 0.28$ & $0.001^{*}$ \\
\hline AIP & $0.14 \pm 0.18$ & $-0.00 \pm 0.14$ & $0.14 \pm 0.04$ & $0.002^{*}$ \\
\hline
\end{tabular}

* significant at $\mathrm{p}<0.05, \mathrm{TC}=$ Total cholesterol, AIP $=$ atherogenic index of plasma, TG=triglycerides, VLDL-C= very low density lipoprotein cholesterol, HDL-C=high density lipoprotein cholesterol, LDL-C= low density lipoprotein cholesterol, FPG=fasting plasma glucose. 


\section{Discussion}

Metabolic abnormalities with regards to alterations in the homeostasis of plasma lipids and some micro and macronutrients were determined in HIV infection with or without HAART. In this study, lower levels of TC, TG, LDL-C, VLDL-C and AIP and higher BMI and CD4+ T cell count were seen in HIV sero-negative controls compared to HIV sero-positive subjects on HAART and HAART naïve. These findings are consistent with observations from other studies (3). Disturbances in plasma lipid have been shown to be a common finding in HAART naïve HIV infected individuals even in the absence of major host related risk factors for dyslipidemia, such as high blood pressure, diabetes mellitus and obesity. Dyslipidemia in HIV-infected individuals has been attributed to increased apolipoprotein levels, increased hepatic synthesis of TG and VLDL-C, decreased clearance of TG, acute-phase proteins, increase in circulating cytokines such as IL-6 and IFN- $\alpha$ and also to the effects of viral infection itself . The levels of total cholesterol (TC) and high-density lipoprotein-cholesterol (HDL-C) have been shown to be rather low in the early stages of HIV infection (18). However, the progressive lowering of CD4+ $\mathrm{T}$ cell lymphocyte counts resulting from destruction by HIV has been reported to induce a reduced clearance of lowdensity lipoprotein-cholesterol (LDL-C) particles, a decrease in HDL-C and an elevation in the triglyceride levels which may positively correlate to the degree of viraemia (19). HAART has also been shown to affects the hydrolysis of triglyceride-rich lipoproteins and tissue lipase, disrupts normal postprandial free fatty acid and lipoprotein catabolism and interferes with peripheral fatty acid trapping (20). However, no significant difference was observed in the HDL-C levels of controls compared to HIV on HAART and HAART naive. The atherogenic index of plasma (AIP) was significantly higher in HIV subjects on HAART compared to HAART naïve seropositive subjects and the controls studied $(\mathrm{p}<0.05)$. Atherogenic index of plasma is a ratio of TG and HDL-C and has been successfully used as an additional index for assessing cardiovascular risk factors. It has been shown that AIP values of -0.3 to 0.1 are associated with low, 0.1 to 0.24 with medium and above 0.24 with high cardiovascular risks (21). The findings of this study indicate that HIV subjects on HAART treatment with mean AIP values of 0.1 are at a medium risk of developing cardiovascular diseases compared to the treatment naive subjects and controls who are at low risk for developing cardiovascular disease. Consistent with our findings, higher atherogenic dyslipidemia ratio has also been demonstrated in HIV seropositive individuals compared to controls (22).

The fasting plasma glucose levels of HIV seropositive individuals on HAART and HAART naïve were significantly higher than those of the sero-negative controls studied. Alterations in the normal metabolism of glucose and insulin resistance have been described in HIV infection (23). Pathways underlying alterations in glucose metabolism in HIV infection and HAART are poorly understood but have been related to specific drug toxicities. Increased risk for diabetes have been associated with HAART specifically protease inhibitors (PIs). Hyperglycemia, new-onset diabetes mellitus, exacerbation of existing diabetes mellitus, and diabetic ketoacidosis has been reported in HIV-infected patients taking PIs (23). An in vitro essay with PIs and nucleoside reverse transcriptase inhibitors (NRTIs) showed altered adipocyte functions and decreased adiponectin, a positive regulator of insulin sensitivity. PI's has also been shown to reduce glucose transport mediated by the insulinsensitive glucose transporter Glut4 which is responsible for insulin-stimulated glucose uptake into muscle and adipose tissue and this may influence pancreatic $\beta$-cell insulin secretion (24). Significant hormonal and cytokine alterations that could affect glucose metabolism has been reported to occur in HIV patients with or without HAART. Increased release of TNF- $\alpha$, IL- 6 and IL- 8 by both infected $\mathrm{T}$ cells and adipose tissues has been shown to induce inflammatory insulin resistance (25). HIV 1 accessory protein Tat has been attributed a potential role in initiating or aggravating insulin resistance. Tat is known to activate Nuclear Factor $\kappa \mathrm{B}(\mathrm{NF}-\kappa \mathrm{B})$, which induce TNF- $\alpha$ production, block free fatty acid (FFA) uptake by adipocytes and suppress insulin receptor signaling - all of which could potentially decrease glucose disposal by blunting Glut4 translocation, and promote insulin resistance by increasing serine phosphorylation of insulin receptor substrate-1 (IRS-1) (27). These activities would promote gluconeogenesis and fasting hyperglycemia. An inverse relationship 
between $\mathrm{CD} 4+\mathrm{T}$ cell counts and insulin resistance but no relationships between $\mathrm{CD} 4+\mathrm{T}$ cell counts and fasting glucose concentrations have been reported in HIV positive individuals (26).

HIV sero-negative subjects had higher albumin and A/G ratio and lower globulin levels compared to HIV on HAART and HAART naïve subjects. Similar observations have been documented by other studies (3, 18), who reported elevated levels of globulin and total protein in HIV subjects compared to the controls. Chronic HIV infection induces hypergammaglobulinemia via polyclonal B-cell activation and spontaneous secretion of immunoglobulins by abnormally activated Bcells. But, as an expression of the aberrant immune activation that characterizes untreated HIV infection (3), other globulin fractions are also abnormally elevated. This could thus be the reason for the elevated calculated globulin among HIV HAART naïve subjects. Viral Tat protein has been shown to induce an enhanced ROS production in HIV-infected patients by mitochondrial generation of superoxide anion, which in turn may activate NF- $\kappa B$ (27), thus increasing HIV transcription. Deleterious effects of ROS are neutralized by the body's system of antioxidants which are consumed in the process. Albumin has been described as extracellular antioxidants where albumin constitutes up to $49 \%$ of total plasma antioxidant status (28). It acts by binding copper ions and scavenging hypochlorous acid $(\mathrm{HOCl})$. The scavenging of $\mathrm{HOCl}$ by albumin may be due to the rapid reaction with sulfur hydryl group (SH-group) in the circulation and their degradation (29). Albumin also contains one reduced cysteine residue (Cys34) which constitutes the largest pool of thiols in circulation. Through the reduced Cys34, albumin is able to scavenge hydroxyl radicals (28). Thus, significantly lower levels of serum albumin in HIV seropositive HAART naïve individuals could be a consequence of their increased consumption to buffer the effect of increased free radicals generation and lipid peroxidation associated with HIV infection. The serum albumin concentration therefore appears to be a sensitive predictor of preclinical disease and may therefore be a useful prognostic marker of disease progression in HIV- infected individuals. HIV on HAART on the other hand had higher albumin and A/G ratio and lower total protein and globulin compared to HAART naïve subjects. Increased albumin levels in HIV positive subjects on HAART have been reported 12 months after commencement of HAART. HAART has been shown to induce improvement in the manifestations of B-cell immune deregulation, including reduction in polyclonal activation as measured by immunoglobulin levels, reduction in markers of B-cell immune activation and normalization of B-cell count and B-cell subpopulation distribution (3). This corroborates the effect of HAART on inhibiting immune activation and reduction of disease progression.

Higher levels of vitamin $\mathrm{C}$ and Zinc and lower copper levels were seen in HIV sero-negative controls compared to HIV on HAART and HAART naïve. Higher vitamin $\mathrm{C}$, zinc and copper levels were also seen in HAART naïve compared to HIV on HAART. These results are consistent with the finding of previous studies who independently documented reduced levels of zinc and vitamin $\mathrm{C}, \mathrm{Fe}, \mathrm{Co}, \mathrm{Se}$, vitamin $\mathrm{C}$ and vitamin $\mathrm{E}$ in $\mathrm{HIV}$ subjects compared to the controls and associated the adverse clinical outcome during HIV infection with lower levels of vitamins and micro-mineral deficiencies (30). The combination of malnutrition, malabsorption and exhaustion during detoxification of free radicals could account for the significantly lower levels of these micronutrients in the HIV population. Although HAART has been shown to be associated with a decreased prevalence of opportunistic gastrointestinal diseases and incidence of malnutrition, gastrointestinal infections and severe gastroenteritis which alter micronutrient absorption, may persist after HAART initiation. Several HIV medications, particularly NRTIs, have been shown to inhibit the replication of mitochondrial DNA and cause vomiting and diarrhea that can reduce the absorption or increase the losses of several micronutrients (31). Among HIV-positive persons not receiving HAART, observational studies have shown low or deficient serum concentrations of several micronutrients, including thiamine, selenium, zinc, and vitamins A, Vit B3, B6, $\mathrm{B} 12, \mathrm{C}, \mathrm{D}$, and $\mathrm{E}$ to be individually associated with low CD4 + T cell counts (32). Such associations with CD4+T cell count were however not observed in this present study. Micronutrient interventions have been shown to have cellular and clinical benefits in HIV-positive persons not receiving HAART. In HIV-infected $\mathrm{T}$ lymphocytes, vitamin $\mathrm{C}$ has been shown to reduce reverse transcriptase activity and vitamin $\mathrm{E}$ to reduce NF- 
$\kappa \mathrm{B}$ concentrations and the production of oxidant compounds (32). The observed higher copper levels in HIV on HAART may result from compensatory increase to buffer the effects of depleted antioxidants. The body tends to retain copper to combat heavy antioxidant demands (33). HIV infection has also been reported to be associated with increased proinflammatory cytokines, which was reported to lower the plasma levels of $\mathrm{Fe}$ and $\mathrm{Zn}$ but raises the level of $\mathrm{Cu}$ (34). Contrary to our findings, no significant differences were reported in the levels of zinc and vitamin $\mathrm{C}$ in HIV subjects receiving HAART compared to HAART naïve subjects. HIV medications have been reported to have a direct effect on the synthesis and metabolism of certain micronutrients. Some PIs have been demonstrated in cell and tissue cultures to significantly increase retinal dehydrogenase activity, an enzyme responsible for the production of alltrans retinoic acid, a precursor of vitamin $\mathrm{A}$ and also induce retinal dehydrogenase gene expression (35).

\section{Conclusion}

The findings of this study suggests that HIV infection and HAART regimen seems to be associated with changes in the homeostasis of total proteins and albumin, glucose, antioxidant micronutrients and dyslipidemia which could predispose to development of cardiovascular complications. Anti-oxidant micronutrient supplementation maybe beneficial in preventing disease progression and development of non-infectious HIV related comorbidities.

\section{Acknowledgement}

The authors are grateful to the staff of Voluntary Counseling and Testing (VCT) unit and HIV Clinic of University of Calabar Teaching Hospital, (UCTH) Calabar, South-South Nigeria for their assistance in subject recruitment.

Ethics Committee Approval: Ethics Committee approval was received for this study from the ethics committee.

Informed Consent: Written informed consent was obtained from patients who participated in this study.

Peer-review: Externally peer-reviewed.

Conflict of Interest: No conflict of interest was declared by the author.
Financial Disclosure: The author declared that this study has received no financial support.

\section{References}

1. Martin A, EmeryS. Metabolic disorders and cardiovascular consequences of HIV infection and antiretroviral therapy. Epert Rev Clin Pharmacol 2009;2:381-390.

2. Sellmeyer DE, Grunfeld C. Endocrine and metabolic disturbances in human immunodeficiency virus infection and the acquired immune deficiency syndrome. Endocr Rev 1996; 17:518-532.

3. Serpa J, Haque D, Valayam J, Breaux K, RodriguezBarradas MC. Effect of combination antiretroviral treatment on total protein and calculated globulin levels among HIVinfected patients. International Journal of Infectious Diseases 2010; 14S:e41-e44.

4. Drain PK, Kupka R, Mugusi F, Fawzi WW. Micronutrients in HIV-positive persons receiving highly active antiretroviral therapy. American Journal of Clinical Nutrition 2007; 85(2):333-345.

5. Cunningham-Rundles $\mathrm{S}$, McNeeley DF, Moon A. Mechanism of nutrient modulation of the immune response. $\mathrm{J}$ Allergy Clin Immunol 2005; 115:1119-1128.

6. World Health Organization. Consolidated guidelines on the use of antiretroviral drugs for treating and preventing HIV infection, 2013.

7. Arai H, Petchclai B, Khupulsup K, Kurimura T, Takeda K. Evaluation of a rapid immunochromatographic test for detection of antibodies to human immunodeficiency virus. $J$ Clin Microbiol 1999;37:367-370.

8. Mandy FF, Bergeron M, Minkus T. Principles of flow cytometry. Transfus Sci 1995;16:303-314.

9. Laboratory Methods Committee of the Lipid Research Clinics Program: Cholesterol and triglyceride concentrations in serum/plasma pairs. Clin Chem 1977;23:60-63

10. Fossati P, Prencipe L. Serum triglycerides determined colorimetrically with an enzyme that produces hydrogen peroxide. Clinical chemistry 1982; 28(10):2077-2080.

11. Natio HK. High-density lipoprotein (HDL) cholesterol. In: Kaplan L A, Pesce AJ, Kazmierczak SC. editors, Clinical Chemistry, theory, analysis and correlations.4th ed, Mosby Inc, St Louis USA, 1984, p.437,1207-1213.

12. Friedewald WT, Levy RI, Fredrickson DS. Estimation of the concentration of low-density lipoprotein cholesterol in plasma, without use of the preparative ultracentrifuge. Clinical Chemistry 1972; 18: 499-502.

13. Dobiasova M, Frohlich J. The plasma parameter log (TG/HDL-C) as an atherogenic index: correlation with lipoprotein size and esterification rate in apoB-lipoproteindepleted plasma (FER(HDL)). Clinical Biochemistry 2001; 34:583-588.

14. Roe JH, Kuether CA. Determination of ascorbic acid in whole blood and urine through the 2:4- dinitrophenylhydrazine derivateof dehydroascorbic acid. J. biol. Chem 1943; 147:399406.

15. Fenk CJ, Kaufman N, Gerbig D.G. Protein detection and measurement. J Chem Educ 2007; 84:1676-1678.

16. Doumas BT, Biggs HG. Determination of serum albumin,- 
Standard methods of clinical chemistry, Acad. Press. N.Y. 1972; 7 : p.175-188.

17. Everson ME. Spectrophotometric techniques. In: Burtis CA, Ashwood ER, editors, Tietz Textbook of Clinical Chemistry, W. B. Saunders, Philadelphia, Pa, USA, 3rd ed, 1999, p. 75-93.

18. Cunha J, Maselli LMF, Stern ACB, Spada C, Bydlowski SP. Impact of antiretroviral therapy on lipid metabolism of human immunodeficiency virus-infected patients: Old and new drugs World J Virol 2015;4:56-77.

19. Cerrato E, Calcagno A, D'Ascenzo F, Biondi-Zoccai G. Cardiovascular disease in HIV patients: from bench to bedside and backwards. Open heart 2015;2:e00174.

20. Mulligan K, Grunfeld C, Tai VW, Algren H. Hyperlipidemia and insulin resistance are induced by protease inhibitors independent of changes in body composition in patients with HIV infection. J Acquir Immune Defic Syndr 2000; 23:35-43.

21. Agu CE, Usoro CAO, Inaku KO, Nsonwu AC, Offor SJ. Cross-sectional analysis of cardiovascular risk markers among obese males and females in Southern Nigeria. Scholars Journal of Applied Medical Sciences 2016; 4(5A):1471-1478.

22. Ngatchou W, Lemogoum D, Ndobo P, Yagnigni E. Increased burden and severity of metabolic syndrome and arterial stiffness in treatment-naive HIV + patients from Cameroon. Vasc Health Risk Manag 2013;9:509-516.

23. Hima BA, Naga AP. Adverse effects of highly active antiretroviral therapy (HAART). J Antivir Antiretrovir 2011; 3:060-64.

24. Grinspoon S. Diabetes mellitus, cardiovascular risk, and HIV disease. Circulation 2009; 119:770-772.

25. Limone $P$, Biglino $A$, Valle $M$, Degioanni $M$. Insulin resistance in HIV-infected patients: relationship with proinflammatory cytokines released by peripheral leukocytes. Journal of Infection 2003;47(1):52-58.

26. Brown TT, Tassiopoulos K, Bosch RJ, Shikuma C, McComsey GA. Association between systemic inflammation and incident diabetes in HIV-infected patients after initiation of antiretroviral therapy. Diabetes Care 2010; 33:2244-2249.

27. Schreck R, Rieber P, Baeuerle PA. Reactive oxygen intermediates as apparently widely used messengers in the activation of the NF- $\kappa$ B transcription factor and HIV-1. The EMBO Journal 1991;10:2247-2258.

28. Halliwell B. Albumin an important extracellular antioxidant? Biochem. Pharmacol. 1988; 37:569-571.

29. $\mathrm{Hu}$ ML, Louie S, Cross, CE, Motchnik, P, Halliwell B. Antioxidant protection against hypochlorous acid in human plasma. J Lab Clin Med 1993; 121: 257-262.

30. Pasupathi P, Ramchandran T, Sindhu PJ, Saranavan G, Bakthavathsalam G. Enhanced oxidative stress markers and antioxidant imbalance in HIV infection and AIDS patients. Journal of Scientific Research 2009; 1:370-380.

31. Cote HC, Brumme ZL, Craib KJ. Changes in mitochondrial DNA as a marker of nucleoside toxicity in HIV patients. $N$ Engl J Med 2002; 346:811-820.

32. Visser ME, Maartens G, Kossew G, Hussey GD. Plasma vitamin and zinc concentrations in HIV-infected adults in Cape Town, South Africa. Br J Nutr 2003; 89:475-482.

33. Egbe ER, Nsonwu-Anyanwu AC, Offor SJ, Usoro CAO,
Etukudo MH, Egbe DI. Cement dust exposure and perturbations in some elements and lung and liver functions of cement factory workers. Journal of Toxicology 2016:1-7.

34. Biron A, Bobin-Dubigeon C, Volteau C, Piroth L. Metabolic syndrome in French HIV-infected patients: prevalence and predictive factors after 3 years of antiretroviral therapy. AIDS research and human retroviruses 2012; 28:1672-1678.

35. Toma E, Devost D, Chow LN, Bhat PV. HIV-protease inhibitors alter retinoic acid synthesis. AIDS 2001;5:19791984.

Submit your next manuscript to the JICM and take full advantage of:

- Convenient online submission,

- Thorough peer review, Fast Response,

- No charges,

- Immediate publication on acceptance,

- Inclusion in Scopemed and High quality indexes,

- Research which is freely available for redistribution of the worldwide literature

To submit your manuscript, click on $h t t p: / / w w w . j i a c m . c o m$

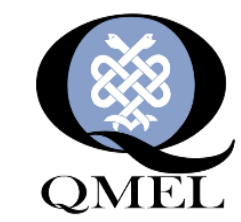

Medicine \& Publishing

Published by The ${ }^{\circledR}$ QMEL.org

Medicine \& Education \& Library

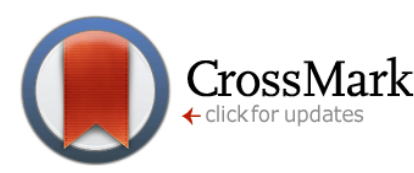

